\title{
Needs Analysis for Development Authentic Assessment Oriented NGSS
}

\author{
Tiara Obrilian Cahyanti \\ Science Education Master \\ Program \\ Universitas Sebelas Maret \\ Surakarta, Indonesia \\ tiaraobriliancahyanti@student.uns. \\ ac.id
}

\author{
Sukarmin \\ Science Education Master \\ Program \\ Universitas Sebelas Maret \\ Surakarta, Indonesia \\ sukarmin67@staff.uns.ac.id
}

\author{
Ashadi \\ Science Education Master \\ Program \\ Universitas Sebelas Maret \\ Surakarta, Indonesia \\ ashadi.uns.ac.id@staff.uns.ac.id
}

\begin{abstract}
Needs analysis on the learning process is needed to know the needs of schools in order to achieve learning objectives. NGSS is a framework in the $21^{\text {st }}$ century learning which requires the active participation of students in learning Science, Technology, Engineering, and Mathematics (STEM). This research is aimed to analyze teachers' need for authentic assessment oriented NGSS. This is a descriptive research with subjects of this research were 58 junior high school science teachers in Surakarta and surrounding areas. Data in this research collecting from questionnaire, interview, and classroom observation. Based on the result of the research and analysis, it shows that junior high school science teachers in Surakarta and surrounding areas have not used the techniques and assessment according to the competencies measured. Furthermore, assessment used by teacher has not been entirely based on the Performance Expectation in NGSS. The development of authentic assessment oriented NGSS is highly needed by junior high school science teachers in conducting assessment which is oriented towards learning in the $21^{\text {st }}$ century.
\end{abstract}

Keywords-assessment, authentic, NGSS

\section{INTRODUCTION}

Curriculum 2013 is an integrated curriculum developed from the previous curriculum which is Kurikulum Tingkat Satuan Pendidikan (KTSP). Curriculum 2013 requires a science-oriented learning environment that canalize active students or simply stated as student-centered learning. Curriculum 2013 has applied so that students are required to be active in order to participate in digging and processing information independently. The role of teacher in the classroom is only as a facilitator. Curriculum 2013 also requires proper assessment of student learning outcomes under three domains. Not only aspects of knowledge is measured, but attitude and skills domain are also measured as well. This is confirmed by the Menteri Pendidikan dan Kebudayaan (Mendikbud) through its policy, stated that "Curriculum 2013 is expected to result in productive, creative, innovative and affective Indonesian people through strengthening attitudes, skills and integrated knowledge" [3].
The general purpose of assessment is to reward students' learning outcomes due to the evaluation of learning process. Assessment in student learning outcomes should be done well in order to get right information regarding the state of learners. In addition, a good assessment can also provide information about teaching and learning process in classroom by the teacher so it can be used as an evaluation in order to develop and improve learning process in the next lesson.

Assessment in curriculum 2013 is guided by Permendikbud Nomor 23 Tahun 2016 on Standar Penilaian Pendidikan (SNP). SNP is used as a reference for educators, educational units and governments in educational units. Assessment of education plays a role in the process of collecting and processing information to measure the students' achievement due their learning outcomes, including: authentic assessment, self-assessment, portfolio-based assessment, test, daily test, mid test, final exam, competency level test, national exam and school / madrasah examinations [2]. Authentic assessment becomes one of emphases in curriculum 2013. Authentic assessment in curriculum 2013 is expected to provide an overall picture regarding the state of students in learning process, including affective, cognitive and psychomotor domains. [2] Authentic assessment is an activity to assess the students who emphasize what should be assessed, both process and results with various assessment instruments tailored to the demands of competence in Standar Kompetensi (SK) or Kompetensi Inti (KI) and Kompetensi Dasar (KD).

Authentic assessment which is expected to have a positive impact on learning process and evaluation happens to raise a lot criticism in reality. Implementation of current authentic assessment nowadays can not be done completely by the teachers. This problem happens because teachers feel that it is difficult to do learning and assessment well. It had been found too that the science teachers did not have enough ability in applying assessment during science instruction because they had less understanding about the nature of assessment [8]. This is reinforced by the results of monitoring and evaluation conducted by the 
Ministry of Education and Culture which states that approximately $60 \%$ of respondents educators said they have not been able to design, implement, process, report and utilize the results of the assessment properly. In addition, the main difficulties faced by educators are formulating indicators, preparing instrument grains, and conducting an attitude assessment using a variety of techniques. Many educators lack the confidence in carrying out a skill assessment, because they have not fully understood how to draw up skills instruments and rubrics. Some educators admit that they are not confident in developing points of knowledge, because they do not understand how to formulate indicators and formulate grain questions for factual, conceptual, and procedural knowledge, combined with low to high level thinking skills. [7]. Other studies conducted by Efendi and Rustaman on prospective science teachers resulted that they had limited ability to prepare the assessment rubric [9]. Moreover, research conducted by Wijayanti and Sungkono resulted that teacher is lack of creativity to give real example whis is appropriate with daily life and teacher does not use intrument in the learning process [14]. In addition, the demands of curriculum 2013 requires assessment of learning outcomes, including assessment of affective, cognitive and psychomotor at the same time.

Authentic assessment is a very appropriate assessment used to improve student competence. The implementation of authentic assessment on student tasks is very useful to improve the competence, mindset, and creativity of students [11]. Authentic assessment can be integrated with several competencies such as critical thinking skills, HOTS, etc. Research conducted by Widowati, et al (2016) the development of authentic assessment based on scientific literacy used to achieve educational goals and improve the quality of scientific literacy in surveys conducted by PISA [12]

Permendikbud Nomor 66 Tahun 2013 stated that authentic assessment is a comprehensive assessment to assess input, process and output of learning. This definition of authentic assessment has not only emphasized the end of learning, but it also be held from the beginning of learning and during the learning process. Furthermore, it also participates in the assessment of learners so as to describe the achievement of overall competences. The purpose of authentic assessment is to provide valid and accurate information about what the learners know and can do from the learning process [4].

There are four common characteristics of authentic assessment [1]. These characteristics include: 1) Real world tasks, tasks assigned to students are tasks related to daily life and occurred in the environment. 2) Collaborative assessment, authentic assessment is an assessment that combines aspects of cognitive, affective and psychomotor. 3) Co-constructed assessment, authentic assessment is a constructive assessment and develops the learners' abilities as a whole and comprehensive. 4) Multiple products and artifacts, authentic judgments not only result in the same scoring product and current or applicable in the characteristic at that only time.

Next Generation Science Standards (NGSS) describes standards that must be achieved by learners in science classroom. NGSS is a new standard in science learning that awakens and builds student interest in Science, Technology, Engineering and Mathematics (STEM). The NGSS provide an opportunity to include medicine, engineering, forensics, and other applicable sciences in courses that deliver the standards in ways that interest students and may give them a desire to pursue STEM careers [6]. Science, engineering and technology permeate almost every facet of the modern life, the most pressing current and future challenges [5]. NGSS is the key to overcome the challenges of education in $21^{\text {st }}$ century that have the vision to build knowledge-based society with skills such as: information, communication, technology (ICT) skill and media literacy skill, problem solving skill, critical thinking skill, effective communication skill and collaborative skill.

Students need the opportunity to engage in learning process that incorporates three NGSS dimensions through real-world experience in the classroom. The active involvement of students in Science and Engineering Practices (SEPs) in the context of Disciplinary Core Ideas (DCIs) and Crosscutting Concepts (CCs) will be seen when learning is in line with the framework and NGSS. Students will be active in guided learning within questions that arise from actual phenomena or problems of engineering design. Students will be supported to across units and courses in constructing the understanding in line with DCIs. Students will have the opportunity to apply science knowledge in explaining phenomena or designing solutions from real-world problems. Interaction between students with each other will be intertwined because they carry out investigations, present data, interpret evidence, gather additional information and create explanations of models and arguments.

In general, the goals of science education curriculum in Indonesia are fostering students to appreciate and practice their religion, integrating character education in learning science, developing students' cognitive, psychomotor and affective skills, and improving students' science process skills [13]. The integration of NGSS in curriculum 2013 involves the concept of engineering and technology in learning process. Learning is more focused on the investigation due to the problem or phenomena in life through Science and Engineering practices. In addition, science learning will be linked to various disciplines through crosscutting concepts. Classroom-based assessment in NGSS combines knowledge and practices (skills) aspects, in which the knowledge and practice aspects are also subject to assessment in curriculum 2013. The purpose of this research is to analyze teachers' need for the development of authentic assessment oriented NGSS. 


\section{METHOD}

This research is a descriptive research that is aimed to figure out teachers' needs about autenthic assessment in school. Descriptive research is a study intended to investigate the circumstances, conditions, situations, events, activities, and others [10]. This research focus on the teachers' response about the development of authentic assessment oriented NGSS. Research subjects were junior high school science teacher who are in Surakarta and surrounding areas. Data collection tools for this research using questionnaire, interview, and classroom observation. The questionnaire has been validated by expert judgment. The questionnaire includes: 1) Learning tools created by teachers, 2) Implementation of assessment by teachers, 3) Implementation of learning in the classroom, and 4) Topic on science education. Questionnaire is distributed to 58 science teacher who are in Surakarta and surrounding areas. Interview techniques are required to obtain information on applying authentic assessments by teachers. interview Observation techniques are used to look at the learning conditions and how the assessment is done by the science teacher.

\section{RESULT AND DISCUSSION}

Questionnaire of teachers' needs-based analysis is distributed to 58 teachers who are in Surakarta and surrounding areas. Questionnaires of teachers' needsbased analysis to the development of authentic assessments' instruments as science teachers' representation due to authentic assessment is carried out as a demand to curriculum 2013. Through the questionnaire, it is obtained an overview and a description of preparation and implementation to authentic assessment at schools. Result of questionnaire is information about teachers' opinion in compiling and applying authentic assessment in learning at school.

Based on the results of questionnaire analysis, obtained information about the opinion of teachers in preparing and applying authentic assessment in school learning. The results of data analysis can be seen in Table 1.

TABLE I. RESULT OF TEACHERS' NEEDS ANALYSIS

\begin{tabular}{|c|c|c|}
\hline Aspect & Indicator & Score \\
\hline \multirow[b]{2}{*}{$\begin{array}{lr}\text { Learning } & \text { tools } \\
\text { created } & \text { by } \\
\text { teachers } & \end{array}$} & $\begin{array}{l}\text { Preparation of learning tools } \\
\text { independently by teachers }\end{array}$ & $83.19 \%$ \\
\hline & $\begin{array}{l}\text { Assessment is carried out by } \\
\text { using techniques and instruments } \\
\text { according to the competencies } \\
\text { measured }\end{array}$ & $47, .84 \%$ \\
\hline \multirow{3}{*}{$\begin{array}{l}\text { Implementation } \\
\text { of assessment } \\
\text { by teachers }\end{array}$} & $\begin{array}{l}\text { Implementation of knowledge } \\
\text { assessment in learning }\end{array}$ & $87, .50 \%$ \\
\hline & $\begin{array}{l}\text { Implementation of attitude and } \\
\text { skill assessment in learning }\end{array}$ & $69, .83 \%$ \\
\hline & $\begin{array}{l}\text { Preparation of a knowledge } \\
\text { assessment test based on Bloom's } \\
\text { Taxonomy }\end{array}$ & $47, .41 \%$ \\
\hline $\begin{array}{l}\text { Implementation } \\
\text { of learning in } \\
\text { the classroom }\end{array}$ & $\begin{array}{l}\text { Integration of international } \\
\text { standards in school learning }\end{array}$ & $41, .37 \%$ \\
\hline
\end{tabular}

\begin{tabular}{|l|l|c|}
\hline \multicolumn{1}{|c|}{ Aspect } & \multicolumn{1}{|c|}{ Indicator } & Score \\
\hline $\begin{array}{l}\text { Topic } \\
\text { science } \\
\text { education }\end{array}$ & on & $41,81 \%$ \\
\hline
\end{tabular}

Based on the results of teachers' needs-based analysis, it can be concluded that the preparation of learning tools in the form of Lesson Plan (RPP), Student Worksheet (LKS) and assessments' instruments have been implemented independently by $83.19 \%$ of teachers in Surakarta and surrounding areas. This reflects that teachers already have understanding and skills in developing learning tools within the applicable curriculum demands. Preparation of learning tools considers several aspects, including students' learning characteristics and learning environment. Consideration of several aspects in the preparation of learning tools is important so that there is conformity between the fact of actual condition of learning at school compared to the expectation of learning implemented by the teacher.

The results of the questionnaire are reinforced by interview and document review. Through document review from study of learning tools created by teachers, it is known that the learning tools owned by teachers fits to preparation of learning tools strategy based on curriculum 2013. Learning tools owned by teachers consist of syllabus, RPP, LKS and assessment rubric. In the interview results, it is known that teachers are obligated to create one-year lesson plan in every new academic year. Lesson plan must be arranged well so that learning process at school can run well and the purpose of education can be realized.

Curriculum 2013 requires assessment of learning, including affective, cognitive and psychomotor aspects. As many as $87.50 \%$ of science teachers in Surakarta and surrounding areas have implemented a knowledge assessment in classroom learning. However, based on the observation, the question of science test prepared by the science teachers has not meet the criteria of questions' preparation yet. Tests compiled by teachers have not been in line with learning indicators and have not adapted to Blooms' taxonomy in cognitive domain. In learning, educators must be able to understand the goals to be achieved as well as competencies that will be obtained by students in the learning that has been taken [11]. Based on the results of the interviews, many teachers have revealed that they have created cognitive-based tests' questions from science text books' example tests, final exam tests and last year test. Whereas in the design of learning tools have been prepared a proper rubric assessment aspects of students' cognitive measurement, but the assessments' rubric has not been applied by teachers due to the process of learning outcomes' assessment.

As many as $69.83 \%$ of science teachers have conducted an affective and psychomotor assessment. However, assessment techniques used by the teachers are still not in line with the designated assessment 
scheme. Teachers' assessment of affective and psychomotor domains is done by looking at the most active and the most passive students in classroom while students within moderate ability are given by average value. The affective and psychomotor assessment rubric has not been used by teachers in evaluating students' learning outcomes. Assessment with such techniques can not deliver proper results according to the condition of the learners so that assessment conducted by teachers has not been able to provide a real picture of actual condition of students in the classroom. Constraints in students' psychomotor assessment happen as the lack of experiment activities or discussions conducted by teachers so that students' psychomotor assessment is only implemented on some material only.

Next Generation Science Standards (NGSS) contains proper educational standard due to content and practice activities enrichment, creating from across disciplines in each of its classes to provide an international standard of education. NGSS is developed into a more effective learning science framework to increase students' involvement in STEM-based learning [6]. The goal of NGSS is to create general guidelines or standards for teaching and to develop greater interest in science among learners so that they prefer science and technology in getting into higher education [6]. This standard is intended to assist learners in understanding scientific concepts, understanding the scientific process, developing and testing, as well as evaluating scientific evidence. NGSS embodies the goal of science learning in the form of Performance Expectations (PEs) which is a statement of what learners should know and do at every level of education.

NGSS is a framework of learning science that is aligned in answering the challenges of preparing the $21^{\text {st }}$ century generation. Also, $21^{\text {st }}$ century science learning has a vision in facilitating students to achieve PEs in NGSS. NGSS-based learning emphasizes engineering design and technology applications. In NGSS learning, concept of engineering is involved in the learning process of science. Concept of engineering is important, considering many advances that occur in the field of science and technology to develop economy of a certain country. In curriculum 2013, concept of engineering and technology has not become the basis for implementation of science learning yet. Some teachers in Surakarta and surrounding areas have not yet integrated concept of engineering and technology in the classroom.

Classroom assessment in NGSS should focus on the accumulation of knowledge and various practices in learning process [6]. This is similar to the assessment in curriculum 2013 which emphasizes aspects of students' cognitive and psychomotor domain during the lesson. The integration between authentic assessment with PEs in NGSS is one of the best strategies in assessment of science learning. There are similarity aspects or dimensions of authentic assessment with PEs within NGSS framework. However, based on observations, the assessment used by teachers has not been correlated with performance expectation in NGSS. The actual fact in the field shows that there are many science teachers who have not yet understand about the nature of NGSS. Knowledge of science education standards in other countries is important for teachers to know. It aims to enable teachers so that they can integrate the standards of education from other countries with existing educational standards in Indonesia. Thus, it can indirectly be the right step in preparing the $21^{\text {st }}$ century generation.

\section{CONCLUSION}

Based on the result of research and analysis, it shows that junior high school science teachers in Surakarta and surrounding areas have not used the techniques and assessment according to the competencies measured. Furthermore, assessment used by teacher has not been entirely based on the Performance Expectation in NGSS. The development of authentic assessment oriented NGSS is highly needed by junior high school science teachers in conducting assessment which is oriented towards learning in the $21^{\text {st }}$ century.

\section{REFERENCES}

[1] Barber, W., King, S., and Buchanan, S, "Problem Based Learning and Authentic Assessment in Digital Pedagogy: Embracing The Role of Collaborative Communities," The Electronic Journal of e-Learning, vol 13(2), 2015, pp.59-67.

[2] Kunandar, Penilaian Autentik. Jakarta: PT. Raja Grafindo Persada, 2013.

[3] Mendikbud, Pedoman Penilaian Hasil Belajar. Jakarta: Kemendikbud, 2013.

[4] Mundilarto, Penilaian Hasil Belajar Fisika. Yogyakarta: Pusat Pengembangan Instruksional Sains (P2IS) Jurdik Fisika FMIPA UNY, 2013.

[5] National Research Council, A Framework for K-12 Science Education: Practices, Crosscutting Concepts, and Core Ideas. Committee on a Conceptual Framework for New K-12 Science Education Standards. Board on Science Education, Division of Behavioral and Social Sciences and Education. Washington, DC: The National Academies Press, 2011.

[6] NGSS Lead States, Next Generation Science Standards: For States, By States. Washington, DC: The National Academic Press, 2013.

[7] Tim Direktorat Pembinaan SMP, Panduan Penilaian oleh Pendidik dan Satuan Pendidikan Sekolah Menengah Pertama. Jakarta: Kementrian Pendidikan dan Kebudayaan, 2017.

[8] N. Y. Rustaman, D. Rusdiana, , and R. Efendi, "Studi Tentang Sikap dan Kompetensi Asesmen Otentik Guru Sains dan Pengembangannya," Laporan Penelitian Unggulan Perguruan Tinggi Tahun ke 1, 2015.

[9] R. Efendi, and N. Y. Rustaman, Proc. International Seminar (MSCEIS) II (Bandung) (College Park: American Institute of Physics), 2015.

[10] S. Arikunto, Prosedur Penelitian: Suatu Pendekatan Praktik. Jakarta: Rineka Cipta, 2013.

[11] W. N. Arlianty, B. W. Febriana, A. Diniaty, and L. Fauzi'ah, "Designing Assignment Using Authentic Assessment," AIP Conf. Proc. 1911, 020016, 2017.

[12] T. Widowati, N. S. Aminah, and Cari, "Pengembangan Instrumen Penilaian Otentik Berbasis Scientific Literacy pada Pembelajaran Fisika di SMA Sebagai Implementasi Kurikulum 2013” Jurnal Inkuiri, Vol 5 (2), 2016, pp. 8-19. 
[13] Haridza, Risa, and K. E. Irving, "The Evolution of Indonesian and American Science Education Curriculum: A Comparison Study," EDUCARE: International Journal for Educational Studies, Vol.9(2), February,. Bandung, Indonesia: Minda Masagi Press owned by ASPENSI, ISSN 1979-7877, 2017, pp. 95-110.
[14] S. Wijayanti and J. Sungkono, "Need Analysis on Developing Teaching Instruments of Mathematics for Senior High School," Advances in Social Science, Education, and Humanities Research (ASSEHR), vol 158, 2017. 